\title{
Primary Cutaneous B-Cell/T-Cell (Non- MF/SS) Lymphoma N2 TNM Finding v8
}

National Cancer Institute

\section{Source}

National Cancer Institute. Primary Cutaneous B-Cell/T-Cell (Non-MF/SS) Lymphoma N2

TNM Finding v8. NCI Thesaurus. Code C141380.

Involvement of two or more peripheral node regions or involvement of any lymph node region that does not drain an area of current or prior skin involvement. (from AJCC 8th Ed.) 